\title{
Effect on the Product and the Environment Aren Tree Based on Welfare Rural Communities
}

\author{
Zul Azhar ${ }^{1,}$ Idris $^{2}$, Hasdi Aimon ${ }^{3}$, Hari Setia Putra ${ }^{4}$, Mardi $^{5}$ \\ 1, 2, 3, 4 Universitas Negeri Padang, Padang, Indonesia \\ ${ }^{5}$ Universitas Negeri Jakarta, Jakarta, Indonesia \\ *Corresponding Author. Email: idris@ @e.unp.ac.id
}

\begin{abstract}
This article aims to determine the effect of Aren tree-based products and environment on the welfare of communities in hilly areas in Nagari Andaleh Baruh Bukik, Tanah Datar Regency in West Sumatra, Indonesia. The analysis method uses the Smart PLS technique from 3 latent variables (Aren, Environment and Welfare) and 21 manifest variables. Aren variable consists of 9 dimensions, 5 dimensions' environmental variable, welfare variable consists of 7 dimensions, with a questionnaire of 94 sample respondents. The results showed; Jensi Aren Products have a positive and significant effect on the Aren-based Environment. Types of Aren Products have a positive and significant effect on the welfare of Aren farmers. Aren-based environment has a positive and significant effect on the welfare of the community in hilly areas in Nagari Andaleh Baruh Bukik, Tanah Datar Regency, West Sumatra, Indonesia. West Sumatra Indonesia, which has the topography of the area through which Bukit Barisan passes is very prone to landslides and floods, it is advisable to policy makers to cultivate Aren Trees as an environmental conservation plant. So that the Aren tree plant has two functions to support the economy and disaster mitigation so that people live safe, peaceful and prosperous.
\end{abstract}

Keywords: palm products, environment and welfare.

\section{INTRODUCTION}

Aren (Arenga pinnata Merr) is one of the most versatile palm families, can grow at an altitude of 0-1 500 meters above sea level. Even though it is better known as a forest plant, sugar palm has been cultivated well by the Toba Batak tribe since the early 1900s. This plant is spread throughout almost all parts of Indonesia in various agroecosystem conditions. The spread and growth of sugar palm generally takes place naturally. In West Sumatra the Aren plant grows and develops from the dung of wild boar and civets that eat fallen Aren fruit, so that it grows irregularly, including in the research area in Nagari Andaleh Baruh Bukik. Aren plants function as a source of income for the people of Nagari Andaleh, Baruh Bukik, Tanah Datar Regency in West Sumatra, Indonesia. They breed from generation-to-generation Aren, so that Aren trees grow a lot on every slope and hill, even growing a lot near people's homes.

Palm trees can be used as a tool to deal with disasters, especially for areas located in West Sumatra
Province. Disasters that can be overcome by utilizing palm trees as a means of disaster management are landslides, floods, and overcoming drought on the ground when a drought occurs. At least with palm trees it can reduce the intensity of natural disasters.

Opportunities for developing rural areas for the development of Aren plantation are very potential [1], besides that it can absorb labor and improve the welfare of rural communities. What is the reason that there are still many unemployed workers in rural areas, is it possible that Aren farmers are hereditary, or have not found downstream products based on Aren?

The urgency of research according to [2] model of environmental studies and development of palm sugar to solve the problem of palm-based downstream development as an economic source to improve the welfare of people who are environmentally sound in rural areas. There are two policy strategies from model development, namely (i) strategies to improve community welfare (Leni Sugiyowati, Karno 2014), (ii) strategies for Pre-Disaster Mitigation [3]. 


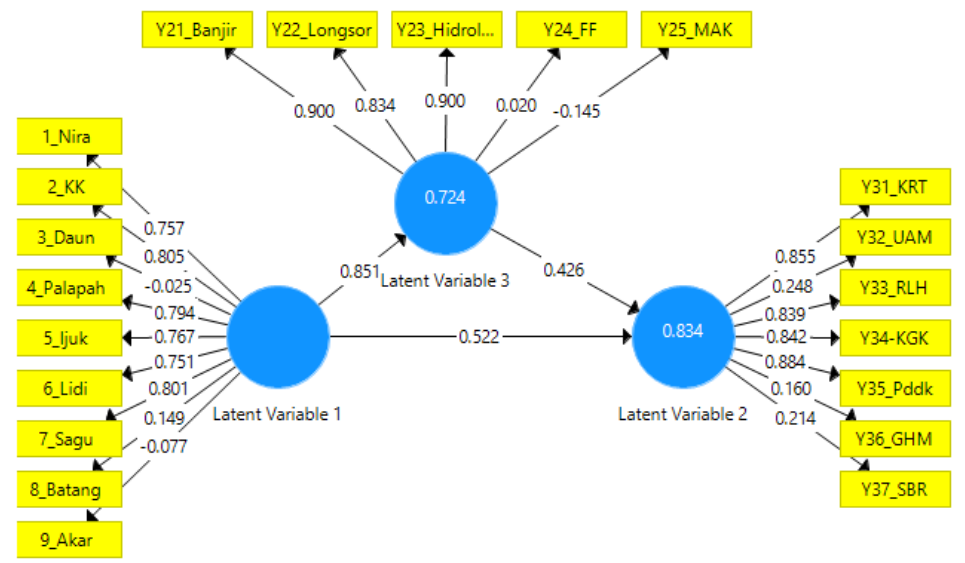

Figure 1 Output Line Coefficient

Description of the research results, from Figure 1 the output path coefficient indicator that has a loading factor $\leq 0.7$ is removed from the model to get a fit path coefficient output. So that of the 9 types of multiproduct indicators of Aren, only 6 types of Aren products (sap, kolang kaling, palapah, palm fiber, sticks, sago) are used by the community economically, while the leaves used to be for cigarettes, the stems are used for floors and walls of chin or barung-barung. (house), the roots to make horse whip bendi (dokar) and medicine are no longer used by the community. Furthermore, of the 5 types of environmental functions, only 3 types are used to reduce (landslides, floods, soil hydrological function during the dry season so that the soil does not dry out), while the three types of economic function indicators (Y2) form very strong constructs. Last of the 7 manifest indicators of latent variable Y3 (welfare of Aren farmers), only 4 loading factors are more than $\geq 0.7$ while 2 types of loading factor $\leq 0.7$ are discarded from the model.

Furthermore, data processing is carried out by using the Calculate PLS Algorithm, so the output of the fit path coefficient is obtained as shown in Figure 2 below;

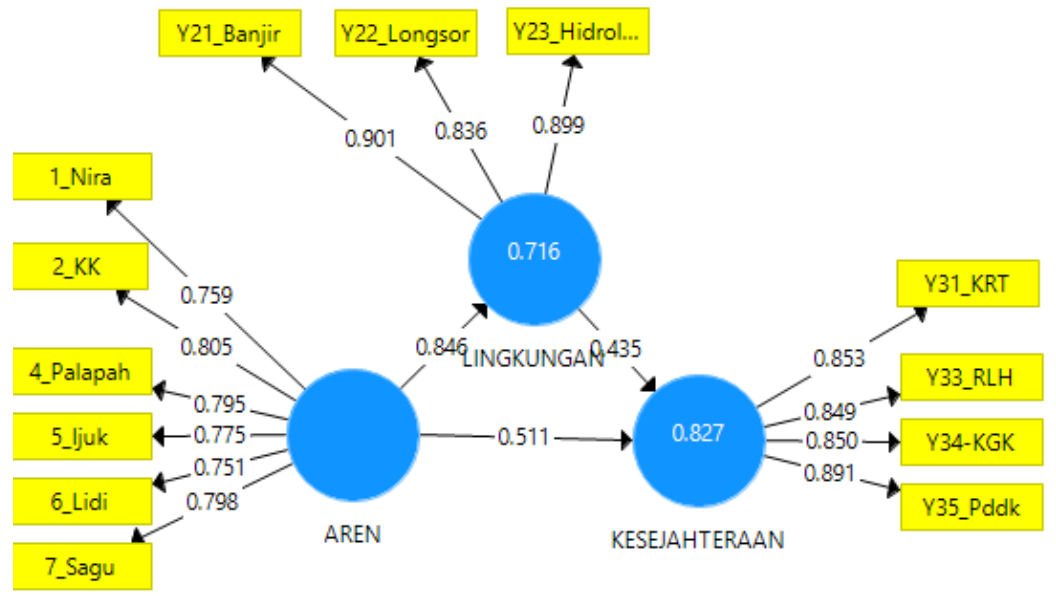

Figure 2 Output Path Fit Coefficient

Furthermore, data processing is carried out by using the PLS Bootstrapping Calculate, so the T Statistical Coefficient Output is obtained as shown in Figure 3 below: 


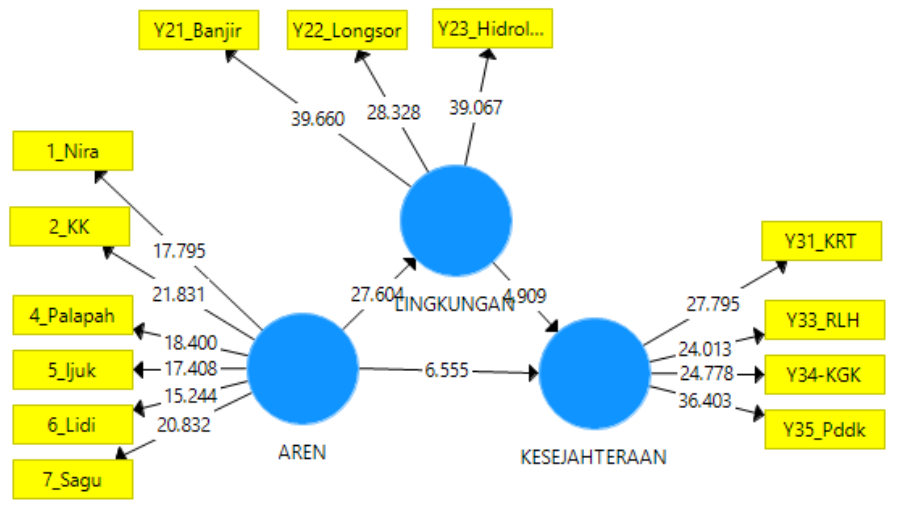

Figure 3 T Statistical Coefficient Output

Path Coefficients

\begin{tabular}{|c|c|c|c|c|c|c|c|}
\hline \multirow[t]{2}{*}{ Mean, STDEV, T-Values, P-Va... } & \multicolumn{2}{|c|}{ Confidence Intervals } & \multicolumn{3}{|c|}{ Confidence Intervals Bias C... } & Samples & \multirow[t]{2}{*}{ Copy to Clipboa } \\
\hline & Original Sampl... & Sampl & le Mean (... & Standard Devia... & T St & tatistics $(\mid \mathrm{O} \ldots .$. & \\
\hline AREN $>$ KESEJAHTERAAN & 0.511 & & 0.515 & 0.078 & & 6.555 & 0.000 \\
\hline AREN $->$ LINGKUNGAN & 0.846 & & 0.846 & 0.031 & & 27.604 & 0.000 \\
\hline LINGKUNGAN -> KESEJAHTERAAN & 0.435 & & 0.431 & 0.089 & & 4.909 & 0.000 \\
\hline
\end{tabular}

Source: Processed Calculate Algorithm Latent Variable sub Latent Variable Correlation, 2020

Based on table 1 above, the following hypothesis testing can be done; (1) Types of Aren Products have a positive and significant effect on the Palm-Based Environment, the results of $\mathrm{t}$ statistic are $27.604 \geq 1.96$ and P Value $0.00 \leq 0.05$. So it can be concluded that there is a positive and significant effect of the types of Aren Products on the Aren-based environment in Nagari Andaleh Baruh Bukik, Tanah Datar Regency. (2) Types of Aren Products have a positive and significant effect on people's welfare, the result of $t$ statistic is $6.555 \geq 1.96$ and P Value $0.000 \leq 0.05$. So that it is concluded that there is a significant effect of the types of palm products on the welfare of the community in Nagari Andaleh Baruh Bukik, Tanah Datar Regency. (3) Aren-based environment has a positive and significant effect on community welfare, the result of $\mathrm{t}$ statistic is $4.909 \geq 1.96$ and $\mathrm{P}$ Value $0.000 \leq 0.05$. So it is concluded that there is a significant influence of the Aren-based environment on the welfare of the community in Nagari Andaleh Baruh Bukik, Tanah Datar Regency.

\section{RESULT AND DISCUSSION}

Types of Aren Products have a positive and significant effect on the Aren-based environment in Nagari Andaleh Baruh Bukik, this research results prove that in this area almost all the land is planted with Aren trees. Since the Aren tree grows, the community feels safe, comfortable, calm and happy because the area has a lot of water for MCK compared to the old days. In line with the research results [4], [5], the economic value and distribution of Aren (Arenga Pinnata), and can be used as Aren tree plants as Benca Mitigation plants [3], so that it can be predicted as the prima donna of the community. countryside [2].

Types of Aren Products have a positive and significant effect on people's welfare. This is said by the Aren Tree Root as a function of the hydrological cycle to regulate groundwater, in line with the results of research (Mulyanie and; Romdani n.d.) in overcoming the problem of natural disasters, various studies have been carried out to conserve nature. One of the research results shows that the palm tree (Arenga pinnata) is a type of palm that has various uses in life after the coconut tree (Cocos nucifera). Apart from its material use, Arenga pinnata can be used to conserve nature and prevent floods and soil erosion. Knowing these uses, the government has intensified the cultivation of palm trees. The government will develop palm tree planting as a national program. This is because the benefits of palm trees are so great, especially in the field of environmental preservation. Sugar palm trees have the longest and most ability to hold the volume of rainwater on the tree. When it rains, each leaf midrib can hold 1-2 liters for several hours. At the age of 5-7 years, palm trees have midribs from the base of the trunk to the tips of the tree, thus giving the soil under the tree a long time to absorb more water, and by itself will store the most groundwater. Temporary research from geologists in [6], palm trees can store and absorb 200 liters of water. To further investigate whether the soil is not prone to drought, further research is needed.

While the indicators; the benefits of Aren trees as a place to protect the biodiversity of flora and fauna so that plants and animals reproduce, and Aren trees to 
preserve nature and beauty do not significantly form their construct.

Multi Produk Aren has a positive and significant effect on the welfare of Aren farmers. The field survey shows that the indicators that form the construct of Welfare of Aren Farmers because; Their household needs are well fulfilled, the house where they live is a decent house, the health and nutrition of their family has been fulfilled, their children can continue their education. While the three indicators; Sugar palm farming business is fun, has been followed by a lifestyle in participating in the community and there is already an opportunity for recreation and cultural activities, not yet strong construct of Aren Farmer Welfare.

\section{CONCLUSION}

The results showed; Types of Aren Products have a positive and significant effect on the environment based on Aren trees. Types of Palm Products have a positive and significant effect on people's welfare. Aren tree-based environment has a positive and significant effect on the welfare of rural communities in hilly areas.

Suggestions that in order to improve the welfare of rural communities, so that they are safe, comfortable, calm and happy and prosperous, the government through the ministry's policy to plant Aren trees as cultivated plants for conservation plants and pave the way to absorb rural labor.

\section{REFERENCES}

[1] R. Mariati, "Production Potential and Development Prospects Aren Plant (Arenga pinnata MERR) In Kalimantan Timur," J. AGRIFOR, 2013.

[2] Z. Azhar, Kajian Lingkungan Dan Perencanaan Pembangunan. Padang: CV Berkah Prima, 2018.

[3] Z. Azhar, Kajian Lingkungan Dan Mitigasi Penanggulangan PraBencana Di Wilayah Rawan Longsor Dan Kekeringan. Padang, 2017.

[4] I. S. W. Rianse et al., "Financial , Economic And Environmental Feasibility Analysis Of Palm Sugar Domestic Industry In Kolaka Indonesia," Int. J. Econ. Manag. Syst., 2016.

[5] E. Purba, O. Affandi, and L. P. Asmono, "Nilai Ekonomi Dan Sebaran Aren (Arenga Pinnata) Di Desa Bukum Dan Desa Suka Maju, Kecamatan Sibolangit," Peronema For. Sci. J., 2014.

[6] E. Mulyanie and A. Romdani, "Pohon Aren Sebagai Tanaman Fungsi Konservasi," J.
Geogr. Media Inf. Pengemb. dan Profesi Kegeografian, 2018. 